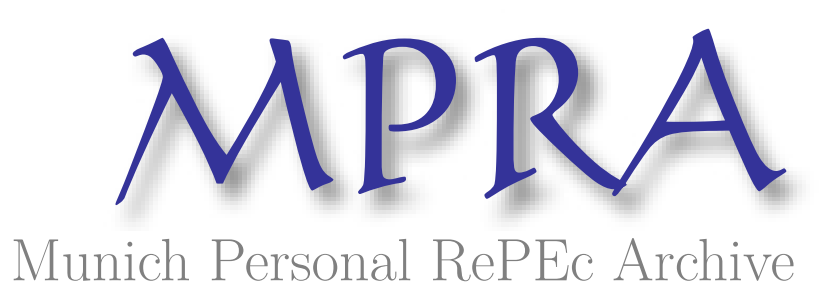

\title{
Trade and structural change in Pacific Asia
}

Chichilnisky, Graciela

1989

Online at https://mpra.ub.uni-muenchen.de/8121/

MPRA Paper No. 8121, posted 07 Apr 2008 04:50 UTC 
lizes the domestic market under protection, but is a competitor in the foreign market. Another is that the domestic firm is a monopolist both in the domestic market and in the foreign market. The analysis is also extended to the case of Cournot duopoly. It is assumed that two domestic firms occupy the domestic and foreign markets between which price discrimination is possible. Since the rival firms in the importing country are not explicitly treated, there is no possibility of changes in oligopolistic interdependence between exporting firms and importcompeting firms.

As the author insists, the model can fit many different configurations of threat situationsi.e. the case of perfect competition and that of monopoly and oligopoly, the case of the quota strategy and that of the VER strategy, the case of fixed quotas and that of proportional ones. etc. However, at the same time, the wide applicability of this book implies the existence of many open guestions. For eximple, it might also be interesting to analyze in what kind of industry the exporting country tends to choose the VER (or quota) strategy: Further, the analysis does not tell us how the importing country determines the quota threat level.

Thus, this book presents a model structure which can be used to inalyze the effect of quota threats in various circumstances, but it also leaves many important questions unanswered. Yoshiyase O vo

Osaka Unitersity

\section{Reference.}

Bhacwat1. Jagutsh N. and Suntvasan, T. N. Optimal Trade Policy and Compensation under Endogenous Uncertainty: The Phenomenon of Market Disruption," J. Inter, Econ.. Nov. 1976, 6(4) pp. $317-36$.

\section{Thade Relations; Commercial Policy; INTERNatIoNAL, ECONOMIC INTEghation}

Trade and struttural change in Pacific Asia. Edited by Colin I, Bradford, Jr. AND William H. Branson. National Bureau of Economic Research Conference Report series. Chicago and London: University of Chicago Press, 1987. Pp. xix, 558. \$58.00. ISBN $0-226-07025-5$.

JEL $87-1093$

This book is a collection of papers by various authors focusing on the economies of Pacific
Asia. The papers were produced for a $1984 \mathrm{sem}$ inar sponsored by the NBE.R and the Malaysian Economic Association.

The book is thorough, and the articles well written and reasonably well connected with each other, which reflects very good editorial work. The volume assembles the established wisdorn concerning a group of countries that have been extremcly successful following rather unconventional strategies, blending for example export promotion with elements of a planned economy and therefore divorcing the conventional association between export promotion and liberal markets. The first essay by the editurs, gives a useful overview of all the issues discussed in the book and ties them together neatly.

There are two types of papers here: the first addresses more or less theoretical issues of trade and development with applications to countries of East and Southeast Asia. These deal inter alia with issues such as the "secret" behind the prosperity of the Gung of Four South Korea, Taiwan. Hong Kong and Singapore) as well as the meaning and success of export-oriented strategies. and more generally of trade patterns bused on the theory of relative advantages in factor use (i.e., the international division of laborl. The second type of papers are less theoretical, and refer to particular issues in particular countries. There are "case studies" of, for example, Singapore trade in manufactures and trade patterns in Taiwan and Thailand.

The first type of paper sets the tone and underlying theoretical structure for the latter type. We have therefore a division of labor within the book: the more theoretical papers are intensive in the use of "intellectual capital" (i.e., economic theory); and the more applied papers are more intensive in the use of "intellectual labor" (i.e., economic data gathering).

Perhaps not surprisingly, the capital intensive papers are produced by economists from industrial countries and appear first in the volume, establishing the book's frame of reference. On the whole, the labor intensive articles are written by economists from the developing countries concerned, within the framework laid by the former papers. I now refer to arguments presented in the book itself to discuss this intellectual division of labor. I consider it less productive than would have been a more evenhanded division of labor, where papers from 
developing countries' economists set the overall thought structure for the trade and development issues which directly concern their countries.

This point can be seen more clearly in relation to a cluster of issues which reappear throughout the book, and which are currently hotly debated within the development and trade literature. These issues are widely referred to under the rubric of "international division of labor." Such division of labor is studied in Pacific Asia vs. the rest of the world. This issue is of importance in determining whether Pacific Asia's NICs represent exceptional cases or replicable models. The editors ask: "Are the NIC's sui generis" in their use of factors)? The meaning of the NIC category explored most thoroughly in this volume is the relationship between exceptional export performance, especially in the growth of manufactured exports. and dynamic development, by which is meant some combination of rapid aggregate conomic growth and structural change.

A number of broad issues are recurrent throughout the book, in particular the relationship of tactor proportions to the composition of trade, the impact of abundant resource endowments on industrialization and manufactured exports, and the rupidity of adjustment of the patterns of trade and structures of production to dynamic growth in different "tiers" of economies" isee p. 7).

On page 12 "Factor Proportions and Trade" the editors further develop this theme:

Countries it given moments in time can be thought of as being on a ladder of comparative advantage, thered aceording to thesr standing in factor endowments. Data in the papers by Bradford and Kranse confirm that the composition of exports from Pacific Asia reflects different factor intensities among countries and over time. Moving up the ladder of comparative advantage, natural-resource-intensive exports. dimnish continuously as a percentage of total exports. labor-intensive exports surge and fade, and physical and human capital-intensive exports increase their share.

The very substantial preponderance of lahorintensive exports from the Asian NICs is clearly manifested in the data in Bradford's paper as is the increase in physical and human capital exports. The nascent rise of labor-intensive exports from the next-tier NICs in the 1970s is also apparent. Accelerated structural change of exports is evident in the European NICs and Indonesia. where natural resource exports generate the foreign exchange required for growth.

The issue here is the applicability of the theory of the international division of labor to the success of the Pacific NICs. There are two reasons why the traditional theory does not apply: one is that free markets were not the rule but the exception in these successful expurt promotion cases. The book makes this point clear see, e.g. pp. 16-20). The theory of the division of labor, which predicts growth and weltare benefits from labor intensive specialization in lahor rich countries, is certainly based on "free markets, and does not apply, at least not mmediately, to "dirigiste" economies.

The second point is perhaps mme interesting. It is not specialization in labor intensive exports but rather the swift move away from them that characterizes these successful VICs, as the data presented here also show, What worked for the NIC.s is the opposite of what is predicted by the conventional theory of the division of labor.

The quote from the editurs chapter provided above shows that they view this divergence as the structural change involved in "climbing up" the fuctor intensity ladder. The conventional view is of course that this ladder is climbed as labor becomes more scuree because the pull in this factor through increased production of labor intensive goods leads naturally to higher wages and thus more use of capitul.

However, there is no coherent model showing how specialization in labor intensive exports leads to climbing up the factor intensity ladder towards more capital intensive exports. There: are, to the contrary, very good theories showing that specialization in labor intensive exports. far from being a step up the ladder, could be a trap leading to lower wage's and more poverty. and to the same or more labor intensity, rather than less. I refer to Arthur Lewis' celebrated dynamic model of development with unlimited supplies of labor, and more recent pieces in the 1980 s showing such effects in a general equilibrium model of trade (Chichilnisky, "Terms of Trade and Domestic Distribution: ExportI ed Growth with Abundant Labour. "J. Derel. Econ., Apr. 1981, 8(2), pp. 163-92).

In sum: what requires explanation is how these countries climbed the factor intensity ladder, how they succeeded in defying conven- 
tional wistom in their use of labor. how they controverted theories from industrial countries advising them to specialize in labor intensive exports and adopt freer markets, and how they used policy in a "dirigiste" fishion to escape the labor intensive trap and move, through directed structural change, into capital intensive and more lucrative exports. The book does not provide answers to these most important questions nor do the economic theories proposed here (by economists from industrial countries: advance our theoretical understanding of these puzzles. But these excellent essays improve our understanding of the questions by focusing our thoughts on them.

\section{Graciela Chichilnisky}

\section{Coltumbia University}

430 Balavee of Payments; Inteknational FiNANCE

Dollars, debts, and deficits. By Rudicken Dorsbuscin. Letven; Leuven University Press; Cambridge, MA and London: MIT Press, 1986. Pp. 240. \$22.50. ISBN 0-26204085-9.

$J E L \quad 88-0159$

Rudiger Dornbusch has become an international legend of sorts among policy-oriented economists and policy makers. He shuttles around the world advising ministers and Central Bank governors, and presenting his views on a variety of policy issues to diverse groups of politicians, academics and businessmen. He has written policy pieces on virtually every Latin American country - his favorites being Argentina, Brazil, Mexico, Chile and Peruon most of the continental European nations, on Korea, Australia and the United Kingdom, among others. This book collects a sample of Dornbusch's recent policy writings. It contains eight articles and is divided in three parts: exchange rate problems and the dollar, the LDC's debt problem, and Europe's fiscal policies and growth. With the exception of the first and last chapters-which are adapted from testimony before the U.S. Senate and a lecture presented at Kings College, London-all of the chapters have been previously published in journals or collections. In addition to the eight chapters Dombusch has written introductions to each of the three parts of the book; these are not mere summaries, but rather succulent policy pieces in their own right. The fact that this is a collection of policy papers should not deceive the prospective reader. These are not funky or soft pieces. Quite on the contrary, every paper is rooted in economic theory and a number of them include simple, and yet powerful, formal models that help focus the discussion.

In spite of the fact that the subjects covered are diverse, Durnbusch's preoccupation with fiscal policy constraints is the clear unifying therne that runs from article to article. When it comes to macroeconomics. Dornbusch is, without doubt, a fiscalist. He thinks that fiscal policy can have important effects in the short run. In that regard this book presents a view that is very different from that of the recent vintage of equilibrium macroeconomics. For Dornibusch, agents face incomplete information and can make mistakes: disequilibrium sitıations are common and, consequently, there is whar roum for policy.

The first part of the book- Chapters 1 through 3 -deals with the crucial issue of equilibrium and disequilibrium real exchange rates (RERsi, and centers on the erratic behavior of the dollar since 1980). This problem has recently occupied the effurts of a number of economists. The key question is how to explain the large deviations from purchasing power parity (PPP) that have been observed since the abandonment of the Bretton Woods system in 1973. More specifically, the question is how to disentangle RER movements that are justified by changes in "fundamentals" - that is cquilibrium movements in REHs - from unjustified or disequilibrium RER movements.

Chipters 2 and 3 deal more specifically with the behavior of the floating rate system. The discussion follows a by now well-known line. After documenting "excessive" exchange rate volatility (not anticipated by the proponents of Hexible rates in the 1950s and 1960s Dornbusch proposes a number of possible theoretical explanations that include bubbles, peso problems and other irregularities. He then discusses possible cures. In both chapters he strongly argues for "real interest rate equalization taxes." The justification for proposing this type of taxes is simple: disequilibrium movements in real exchange rates stem mainly from real interest rate differentials. Consequently, if we want to avoid 